Research

\title{
The Influence of Work-Life Balance with Work Motivation as Mediating Factor on Job Satisfaction A Prediction toward Transition to New Normal Situation
}

\author{
Inayah Alfatihah ${ }^{1}$, Antonius Soelistyo Nugroho², Elmarian Haessel ${ }^{3}$, Anita \\ Maharani $^{4}$ \\ Business Management Program, Management Program, BINUS Business School Master Program \\ Bina Nusantara University, \\ 1)inayah.alfatihah@binus.ac.id ; ${ }^{2}$ antonius.nugroho@binus.ac.id ; ${ }^{3)}$ elmarian.haessel@binus.ac.id \\ 4) ${ }^{\star}$ anita.maharani@binus.edu \\ ${ }^{*}$ Corresponding author
}

Received: May 4, 2021; Accepted: June 29, 2021; Published: June 30, 2021

To cite this article: Alfatihah, I.,Nugroho,A.S., Haessel,E.\& Maharani,A.(2021). The Influence of Work-Life Balance with Work Motivation as Mediating Factor on Job Satisfaction A Prediction toward Transition to New Normal Situation, The Management Journal of Binaniaga, 6(1), 79-94. doi: 10.33062/mjb.v6i1.431

\begin{abstract}
This study aimed to examine the effect of work-life balance and work motivation on job satisfaction. The literature review used to discuss the dynamics between variables is work-life balance, motivation and job satisfaction. The approach to this research is quantitative, and the number of respondents involved in this study was 212 people who filled out the survey through an online survey. We collect data during new normal situations. The data analysis technique in this study refers to the structural equation model. The results obtained show that all hypotheses are proven. In other words, this study has shown that work-life balance affects job satisfaction, then work motivation affects job satisfaction, and work-life balance can mediate work motivation on job satisfaction.
\end{abstract}

Keywords: job satisfaction, work-life balance, work motivation

\section{INTRODUCTION}

The Covid-19 pandemic situation that we are facing has brought changes to our daily lives. There are restrictions on activities in office areas due to the Covid-19 pandemic situation, which is currently spreading in Indonesia and throughout the world. Every company in Indonesia sets new policies based on regulations issued by the Indonesian government related to the pandemic situation we are facing, one of which is social distancing. The existence of social distancing requires employees to do work in their respective homes. A sudden change in work-life makes every employee have to adapt to a new environment, which impacts our work habits. Based on a survey conducted by Jobstreet Indonesia filled with 5,617 participants regarding changes in work and personal life since the Covid-19 pandemic, most workers or $86 \%$ have experienced some changes since the outbreak. Nearly $46 \%$ of employees are required to work from home, most likely $50 \%$ work for a longer duration, and nearly half (or $48 \%$ ) have changed working hours and do domestic work (Source: jobstreetindonesia.com, 2020).

Currently, companies have opened their operating hours in the office with regulations that they must obey regarding pandemic conditions. As times goes by, we

Inayah Alfatihah, Antonius Soelistyo Nugroho, Elmarian Haessel, and Anita Maharani. The Influence of Work-Life Balance with Work Motivation as Mediating Factor on Job Satisfaction A Prediction toward Transition to New Normal Situation 
anticipate the Covid-19 pandemic by choosing "peace" and "side by side", adopting a new lifestyle that is different from the lifestyle before the Covid-19 pandemic. Each individual continues to fight the spread of the virus while doing activities as usual. We still have to wash our hands, wear a mask, apply physical distance in every activity and, more importantly, in public places. This new pattern or order of life is known as the new normal. New normal situation makes us have to get used to a different work environment. Employees return to work gradually after several months of doing office activities from home. Several countries have implemented the new normal protocol, including Indonesia. Through a Decree from the Minister of Health, the Indonesian government has issued a new normal protocol for offices and industries amid a coronavirus pandemic situation. One of the new regulations that must apply in offices is working from home, determining essential workers who need to continue working or coming to work and workers who can work from home. This situation has provided sudden changes and a different work environment, which is a challenge for us. Some differences feel by individuals and challenges that arise regarding work activities in the new normal transition period. The challenges, such as not communicating freely with colleagues, doing work activities in the office with colleagues are limited, office work still being carried out at home. However, working at home could be not supportive (unstable network connections, time instability, and much time spent by focusing on the computer), personal time is decreasing and make your personal life unbalanced, the feeling of loneliness that sometimes comes, the motivation to work decreases because it seems life becomes passive. Therefore there is no satisfaction in work life. Overall, the new normal transition period shifted our personal and work lives, affecting work motivation that leads to job satisfaction decrease. In recent studies, there is evidence that job satisfaction decreases because an interpersonal conflict has adverse effects on a person (Rubio et al., 2020). Another evidence said that work motivation decreases because the working atmosphere is different, the mood for work increasingly changes when employee tends to push themself try to fit in, and it gives negative feelings regarding with new environments (Panisoara et al., 2020; Purwanto et al., 2020).

A balance between work and life is essential because it can lead to a healthy and prosperous life (mentally and physically). Research done shows that work-life balance affects job satisfaction (Kaliannan et al., 2016; Blackburn et al., 2017; Hasan \& Teng, 2017). Long before the pandemic, the current research found that work-life balance has a positive influence on the level of job satisfaction of employees (Putra et al., 2020). Worklife balance has a positive role in supporting the improvement of job satisfaction (Wolor et al., 2020; Gigauri, 2020) and work motivation which also plays a role in achieving job satisfaction. A positive attitude can make motivation levels higher and trigger job satisfaction. The results show that work motivation has a positive relationship and significant effect on job satisfaction (Rozzaid et al., 2015; Maurya \& Agarwal, 2018; Parimita et al., 2018). However, research done long before the pandemic and during the pandemic found exciting findings when employees are accustom to the new environment, such as work from home. It is a different working atmosphere, affecting their motivation and tends to changes quickly, and it would disappear when they try to push themself (Purwanto et al., 2020; Tovmasyan \& Minasyan, 2020).

Transition to a new normal situation brings change to our life. There are limitations related to the activities that people do, and something that was normal to do and became a habit a long time ago became something to reconsider. Following the protocol by using their mask, keeping their distance from the others, doing some routine medical check-up to available work from the office, going to different cities or countries, and vaccination covid-19 are the attempts to make people get used to being normal as usual.

Inayah Alfatihah, Antonius Soelistyo Nugroho, Elmarian Haessel, and Anita Maharani. The Influence of Work-Life Balance with Work Motivation as Mediating Factor on Job Satisfaction A Prediction toward Transition to New Normal Situation 


\section{Research Question}

Thus, is there an interesting phenomenon related to work-life balance, work motivation and job satisfaction among employees?

\section{REVIEW OF LITERATURE}

Work-life balance defines as a balance between work, family, and individual responsibility, where each individual carries out their obligations by balancing the fulfilment of their personal and work roles and carries out their duties as a partner or parent (Shen, 2011; Chandra, 2012). Work-life balance is rooted in the employee's need to achieve a healthy balance between the desire to participate in work to show a commitment fully and feels comfortable while giving the best effort to the loved ones (Bhalerao, 2013; Daipuria \& Kakar, 2013; Lavoie, 2014; Kelliher et al., 2019). Some studies show that work-life balance has an indirect effect that helps employees improve well-being and improve individual positive attitudes and life strategies (Zheng et al., 2016). The concept of work-life balance lives on the idea that work and personal life complement each other so that perfection is present in one's life. Enjoyment of life and wanting to accomplish something are two concepts that construct an excellent work-life balance (Bataineh, 2019). Organizations need productivity, and to get higher productivity, they look for employees with improved work-life balance because a person with a better work-life balance will contribute meaningfully towards the organization's growth and success (Salolomo \& Agbaeze, 2019). The literature on work-life balance explains that three basic dimensions must be understood and studied in general: social, organizational, and personal (Sánchez-Hernández et al., 2019). Thus, the concept and conditions related to employees' work-life balance have various meanings because each individual has different characteristics and perceptions.

Changing work prospects and pressure from work requires an understanding of maintaining a work-life balance. (Darwish et al., 2020; Hite \& McDonald, 2020). Maintaining a balance between life and work will make good emotional well-being that will keep us motivated. Work-life balance indirectly encourages and improves work motivation and affects individual motivation and personal life (Mahmoud et al., 2020; Shafee et al., 2020). Work-life balance is essential for the company because it plays a role in determining the level of motivation so that it continues to show commitment to work. Moreover, balancing work-life balance and work motivation is needed (Shafee et al., 2020). Previous studies that have already conducted stated a direct effect between worklife balance and work motivation (Oktosatrio, 2018; Shafee et al., 2020; Sabir \& Cura, 2021). With that, the researcher makes the following hypothesis:

\section{H1: Work-Life Balance will positively influence Work Motivation}

Work motivation refers to psychological strength, where the individual determines his behaviour in an organization, the level of persistence in overcoming problems, and self-determination towards their work dimension (Tentama \& Pranungsari, 2016). Motivation defines a stage that considers the direction and persistence of a person in achieving goals (Kocman \& Weber, 2018). The problems with motivation have become a fundamental problem in an organization. Individuals who have a positive attitude towards work situations show a high level of work motivation, and those who behave negatively towards them will show a low work motivation and getting the jobs are not available to fulfil the company's needs. According to Maslow's theory, work motivation can measure several things such as the need for security, social, appreciation, and self-actualization (Rauan \& Tewal, 2019). Work motivation is a potential that exists in humans, developed by outside forces that can affect performance results (Maulana et al., 2020). Motivating employees at work is an essential factor because, with motivation, employees will

Inayah Alfatihah, Antonius Soelistyo Nugroho, Elmarian Haessel, and Anita Maharani. The Influence of Work-Life Balance with Work Motivation as Mediating Factor on Job Satisfaction A Prediction toward Transition to New Normal Situation 
increase enthusiasm in doing their work so that good results can be achieved (Said et al., 2020).

Employees' ability and knowledge will not be affected if not accompanied by a good attitude and an excellent, motivated spirit at work (Sidabutar et al., 2020). Motivation at work is an effort so that every worker can do a good job. It can be said, work motivation questions how workers can mobilize all their potential and all their energies so that employees can work productively to achieve good work results. Work motivation can underlie job satisfaction when workers are very enthusiastic about working so that this enthusiasm can create a sense of job satisfaction by itself (William, 2020). Previous studies that have already conducted stated a direct effect between work motivation and job satisfaction (Rozzaid et al., 2015; Maurya \& Agarwal, 2018). Another research shows that work motivation positively and significantly affects job satisfaction (Parimita et al., 2018; Sidabutar et al., 2020) and concludes that good motivation at work will increase our satisfaction at work. With that, the researcher makes the following hypothesis:

\section{H2: Work Motivation will positively influence Job Satisfaction}

Job satisfaction defines as people who at work feel a sense of satisfaction with their work. Job satisfaction serves as a measure to find out about employees who feel positive or feel pessimistic about their work, so that is the main reason why job satisfaction is present in this study (Davis \& Nestrom, 1985). Job satisfaction is subjective because the level of job satisfaction obtained is different, and the values adopted by each person are different (Muliana \& Makmur, 2016). Employees who are satisfied with their work will have good physical and mental health, which will indirectly impact the company itself. Job satisfaction sees from a description of the response from emotions to a job so that individuals who do a good job will be satisfied (Obeidat et al., 2018).

Job satisfaction can be called a positive and negative emotion from the individual evaluation of how they feel about their level of satisfaction at work (Asbari et al., 2020). According to the study, McCutcheon (2014), work-life balance is a severe problem and a key topic for any working professional. A person's motivation is to collect energetic forces that should energize them to try new things (Manivannan, 2019). As a result, there is a need to investigate the role of motivation in enhancing work satisfaction mediated by WLB (Smith, 2010).

H3: Work-Life Balance will positively mediate by Work Motivation affects Job Satisfaction.

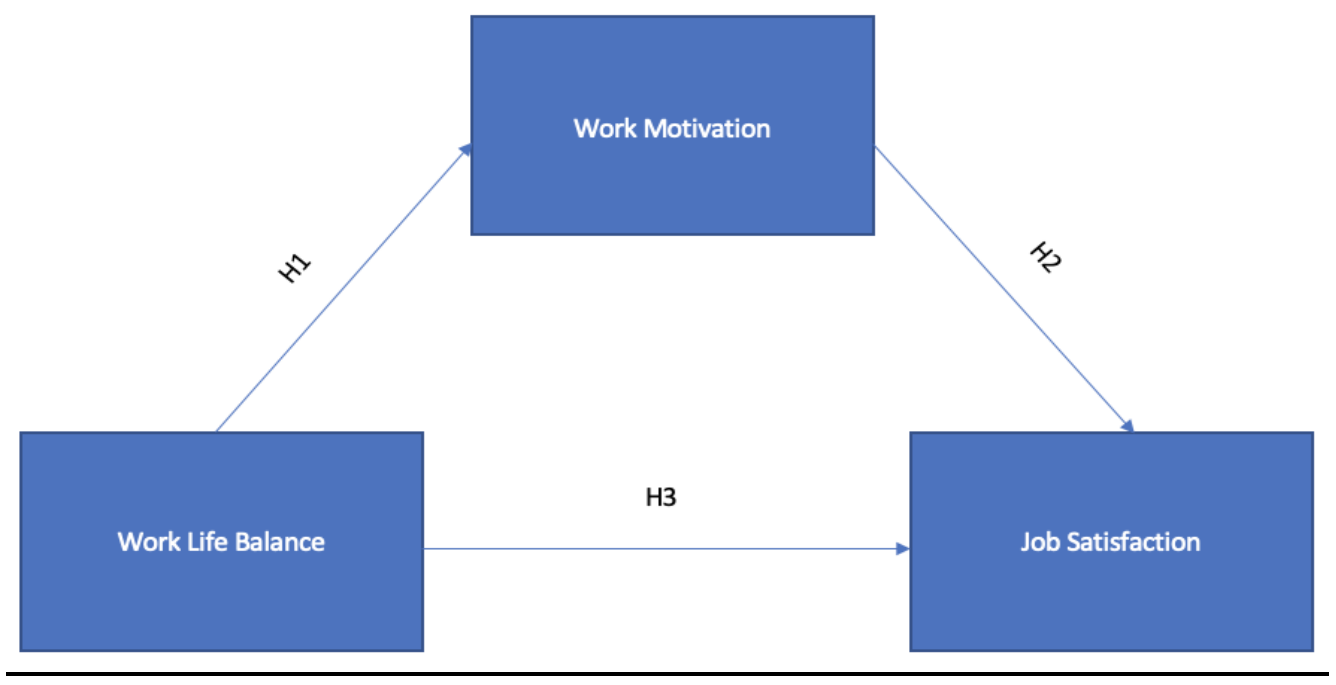

Figure 1. Research Framework

Inayah Alfatihah, Antonius Soelistyo Nugroho, Elmarian Haessel, and Anita Maharani. The Influence of Work-Life Balance with Work Motivation as Mediating Factor on Job Satisfaction A Prediction toward Transition to New Normal Situation 


\section{RESEARCH METHODS}

In this study, the population were all employees that work in companies in Indonesia. The minimum target of respondents will be 200 respondents. Several samples between 30 to 500 respondents are sufficient for conducting research (Sekaran \& Bougie, 2016). The data collected through an online survey from google form. Before they answered the questions, respondents ask if they work as employees. The first part of our questionnaire covers primary demographic data to classify the respondents, and in the second part, the respondents asked to state their preferences and opinion measured using a Likert scale of five levels. The measurement of all variables adapts from validated scales. All respondents will respond five-point scale of Likert and the information about the measurement of the item below:

Work-Life Balance. Twelve items for work-life balance. Initially, there are 15 items scale from Hayman (2005). The scale that we used are from three dimensions of work-life balance, and it is WIPL (Work Interference with Personal Life), PLIW (Personal Life Interference with Work), and WPLE (Work or Personal Life Enhancement). Those items selected will be used to measure work-life balance from employees' point of view regarding the transition to the new standard.

Work Motivation. Work motivation asses using ten items adapted by Tremblay et al., (2009). Items selected will measure work motivation from employees' point of view regarding the new normal transition.

Job Satisfaction. Job satisfaction is measured using the scale from Macdonald \& Maclntyre (1997). We used all of the items because the item questionnaires differ from a relationship with others to a personal feeling about work regarding job satisfaction. The selected items are to measure job satisfaction from employees' point of view regarding the transition to new standard.

\section{RESULTS AND DISCUSSION}

For data collection, a questionnaire gathers through an online survey from Microsoft form. From the survey that we already conducted from 22 March 2021 to 5 April 2021, we collected 247 respondents from the target of 200 respondents, but 35 responded unable to process to next since those 35 were response incorrect manner. Therefore we have 212 response process for further analysis. Respondents profile, as follows.

Table 1. Demographic

\begin{tabular}{llcc}
\hline Variable & Measurement & Frequency & (\%) \\
\hline Gender & Male & 104 & 0.49 \\
& Female & 108 & 0.51 \\
& $20-25$ & 83 & 0.39 \\
& $26-31$ & 38 & 0.18 \\
& $32-37$ & 15 & 0.07 \\
Age & $38-43$ & 20 & 0.10
\end{tabular}

Inayah Alfatihah, Antonius Soelistyo Nugroho, Elmarian Haessel, and Anita Maharani. The Influence of Work-Life Balance with Work Motivation as Mediating Factor on Job Satisfaction A Prediction toward Transition to New Normal Situation 
The Management Journal of BINANIAGA Vol. 06, No. 01, June 2021

p-ISSN: 2527 - 4317, e-ISSN: $2580-149 x$

$6^{\text {th }}$ Accreditation Rating: April 04, $2019-$ April 03, 2024

\begin{tabular}{|c|c|c|c|}
\hline Variable & Measurement & Frequency & (\%) \\
\hline \multirow{7}{*}{ Education } & $44-49$ & 40 & 0.19 \\
\hline & $50-55$ & 13 & 0.06 \\
\hline & $>55$ & 3 & 0.01 \\
\hline & Senior High School & 43 & 0.20 \\
\hline & Associate Degree & 11 & 0.05 \\
\hline & Bachelor & 125 & 0.59 \\
\hline & Master & 33 & 0.16 \\
\hline \multirow[t]{3}{*}{ Marital Status } & Unmarried & 106 & 0.50 \\
\hline & Married & 106 & 0.50 \\
\hline & Primary & 14 & 0.07 \\
\hline \multicolumn{4}{|c|}{ Business Sector } \\
\hline & Secondary & 45 & 0.21 \\
\hline & Tertiary & 153 & 0.72 \\
\hline
\end{tabular}

Our research will reflect the situation within that profile concerning work motivation, work-life balance, and job satisfaction. Most of our respondent's age is between $20-25$ years old; there are no differences between gender, marital status, but most of the respondents graduated as a bachelor, and their work area is within the tertiary business sector (i.e. related to service industry). We distribute the questionnaire and a description to understand and imagine as if they are in a new normal situation when responding to items within the questionnaires.

Our data shows that all items are eligible to analyse, where according to reliability testing, we found at all variables are reliable. However, we follow a second-order method to analyse our model.

Table 2. Reliability

\begin{tabular}{lllll}
\hline & Cronbach's Alpha & Rho_A & AVE & CR \\
\hline WIPL & 0.796 & 0.797 & 0.831 & 0.907 \\
\hline PLIW & 0.552 & 0.607 & 0.526 & 0.766 \\
\hline WPLE & 0.637 & 0.646 & 0.576 & 0.803 \\
\hline WM & 0.843 & 0.843 & 0.516 & 0.881 \\
\hline JS & 0.857 & 0.857 & 0.508 & 0.890 \\
\hline
\end{tabular}

Inayah Alfatihah, Antonius Soelistyo Nugroho, Elmarian Haessel, and Anita Maharani. The Influence of Work-Life Balance with Work Motivation as Mediating Factor on Job Satisfaction A Prediction toward Transition to New Normal Situation 
In this study, the Work-Life balance dimension (WIPL, PLIW, \& WPLE), Work Motivation, and Job Satisfaction have a Cronbach's Alpha and Composite Reliability greater than 0.7. It means that the scale items for this study are reliable. The Average Variance Extracted of Work-Life balance dimension (WIPL, PLIW, \& WPLE), Work Motivation, and Job Satisfaction variables show that the value is more than 0.5 , which means that the data for this study are valid.

However, some items are not included in our analysis because the items failed to meet the outer loading condition requirement. It should be above 0.6 according to Hair et al., (2010), as follows.

Table 3. Outer Loadings

\begin{tabular}{|c|c|c|c|c|c|c|}
\hline & JS & PLIW & WIPL & WLB & WM & WPLE \\
\hline 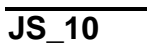 & 0.544 & & & & & \\
\hline JS_2 & 0.640 & & & & & \\
\hline JS_3 & 0.838 & & & & & \\
\hline JS_4 & 0.805 & & & & & \\
\hline JS_5 & 0.800 & & & & & \\
\hline JS_6 & 0.598 & & & & & \\
\hline JS_7 & 0.692 & & & & & \\
\hline JS_9 & 0.730 & & & & & \\
\hline WLB_1 & & & 0.907 & & & \\
\hline WLB_1 & & & & 0.735 & & \\
\hline WLB_10 & & & & & & 0.803 \\
\hline WLB_10 & & & & 0.659 & & \\
\hline WLB_12 & & & & & & 0.708 \\
\hline WLB_2 & & & 0.915 & & & \\
\hline WLB_2 & & & & 0.768 & & \\
\hline WLB_3 & & & & 0.742 & & \\
\hline WLB_5 & & 0.637 & & & & \\
\hline WLB_7 & & 0.668 & & & & \\
\hline WLB_8 & & 0.852 & & & & \\
\hline WLB_8 & & & & 0.693 & & \\
\hline WLB_9 & & & & & & 0.763 \\
\hline WLB_9 & & & & 0.718 & & \\
\hline WM_1 & & & & & 0.734 & \\
\hline WM_10 & & & & & 0.785 & \\
\hline WM_2 & & & & & 0.648 & \\
\hline WM_3 & & & & & 0.756 & \\
\hline WM_4 & & & & & 0.687 & \\
\hline
\end{tabular}

Inayah Alfatihah, Antonius Soelistyo Nugroho, Elmarian Haessel, and Anita Maharani. The Influence of Work-Life Balance with Work Motivation as Mediating Factor on Job Satisfaction A Prediction toward Transition to New Normal Situation 

WM_5
WM_9

From table 3, for Work-Life Balance, in each dimension, all of 2 items of WIPL dimension (WLB 1, WLB 2) can be used, all of 3 items of PLIW dimension (WLB 5, WLB 7, WLB 8) can employ, and all of 3 items of WPLE dimension (WLB 9, WLB 10 , WLB_12) are employed. Likewise for Work Motivation, all of the 7 items which are (WM_1, WM_2, WM_3, WM_4, WM_5, WM_9, WM_10) meet the requirements. Last, for job satisfaction, the subsequent analysis can be processed from the eight remaining items, only six items (JS_2, JS_3, JS_4, JS_5, JS_7, JS_9).

From the reliability results, we proceed to check within the Fornell Lacker value, which aims to see the discriminant validity, and the results show as follows.

Table 4. Discriminant validity

\begin{tabular}{lcccccc}
\hline & JS & PLIW & WIPL & WLB & WM & WPLE \\
\hline JS & 0.713 & & & & & \\
PLIW & 0.482 & 0.725 & & & & \\
WIPL & 0.331 & 0.447 & 0.911 & & & \\
WLB & 0.494 & 0.744 & 0.825 & 0.720 & & \\
WM & 0.613 & 0.478 & 0.322 & 0.486 & 0.718 & \\
WPLE & 0.553 & 0.665 & 0.495 & 0.840 & 0.502 & 0.759
\end{tabular}

Based on table 4 above, all variables are considered valid. Therefore, our next process is to look at the results of $\mathrm{R}$ Square, as follows.

Table 5. R Square

\begin{tabular}{lcc}
\hline & R Square & $\begin{array}{c}\text { R Square } \\
\text { Adjusted }\end{array}$ \\
\hline JS & 0.426 & 0.420 \\
WLB & 0.954 & 0.953 \\
WM & 0.236 & 0.233
\end{tabular}

$R$ Square shows the effect of independent variables on dependent variables. Thus, this research model can explain the phenomenon of $42.6 \%$ for job satisfaction, while for Work-Life Balance is $95.4 \%$, and last is work motivation of $23.6 \%$. After all the steps fulfil, the next step is to look at P-Values and T-Statistics. Based on table 6 below, all the proposed hypotheses are supported because P-Values have a value of 0.000 . P-Values which are used in this research as a basis for decision making should have a value lower than 0.05 . 
Table 6. Hypothesis Testing

\begin{tabular}{|c|c|c|c|c|c|c|}
\hline & $\begin{array}{l}\text { Original Sample } \\
\text { (O) }\end{array}$ & $\begin{array}{c}\text { Sample } \\
\text { Mean (M) }\end{array}$ & $\begin{array}{c}\text { Standard } \\
\text { Deviation } \\
\text { (STDEV) }\end{array}$ & $\begin{array}{c}T \\
\text { Statistics } \\
(\mid \mathrm{O} / \mathrm{STDE} \\
\mathrm{V} \mid)\end{array}$ & P Values & Decision \\
\hline $\begin{array}{l}\text { PLIW } \\
->\text { WLB }\end{array}$ & 0.226 & 0.225 & 0.022 & 10.152 & 0.000 & Supported \\
\hline $\begin{array}{l}\text { WIPL } \\
->\text { WLB }\end{array}$ & 0.507 & 0.505 & 0.029 & 17.252 & 0.000 & Supported \\
\hline $\begin{array}{l}\text { WLB -> } \\
\text { JS }\end{array}$ & 0.256 & 0.254 & 0.076 & 3.371 & 0.001 & Supported \\
\hline $\begin{array}{l}\text { WLB -> } \\
\text { WM }\end{array}$ & 0.486 & 0.491 & 0.053 & 9.133 & 0.000 & Supported \\
\hline $\begin{array}{l}\text { WM -> } \\
\text { JS }\end{array}$ & 0.489 & 0.495 & 0.070 & 7.024 & 0.000 & Supported \\
\hline $\begin{array}{l}\text { WPLE } \\
\text {-> WLB }\end{array}$ & 0.438 & 0.440 & 0.032 & 13.812 & 0.000 & Supported \\
\hline
\end{tabular}

In this section, the analysis is base on the data of 212 respondents by using SmartPLS tools. From the data above, the correlation between Work-Life Balance and Work Motivation shows that the measurement of these variables has a significant effect between Work-Life Balance and Work Motivation (original sample $=0.226, p$-values $=$ $0.000<0.05)$, and the t-statistics result shows $9.133>1,96$, which means that $\mathrm{H} 1$ is supported.

Secondly, the correlation between Work Motivation and Job Satisfaction shows that the measurement of these variables has a significant effect between Work Motivation and Job Satisfaction (original sample $=0.489$, $\mathrm{p}$-values $=0.000$ ) the $\mathrm{t}$-statistics result shows $7.024>1.96$, which means that $\mathrm{H} 2$ is supported.

Table 7. Indirect Effect

\begin{tabular}{|c|c|c|c|c|c|c|}
\hline & $\begin{array}{c}\text { Original } \\
\text { Sample (O) }\end{array}$ & $\begin{array}{c}\text { Sample } \\
\text { Mean (M) }\end{array}$ & $\begin{array}{l}\text { Standard } \\
\text { Deviation } \\
\text { (STDEV) }\end{array}$ & $\begin{array}{c}\text { T Statistics } \\
(|\mathrm{O} / \mathrm{STDEV}|)\end{array}$ & $\begin{array}{c}\text { P } \\
\text { Values }\end{array}$ & Decision \\
\hline$\overline{\text { WLB }->\text { WM }->\text { JS }}$ & 0.238 & 0.243 & 0.041 & 5.801 & 0.000 & upported \\
\hline
\end{tabular}

In the indirect effect, we find that there is a significant effect between Work-Life Balance and Job Satisfaction with Work Motivation as a mediator (original sample $=0.238, \mathrm{p}$ values $=0.000<0.05$ ), and the t-statistics result shows $5.801>1.96$, which means the third hypothesis is also supported, in other words, Work Motivation is an intermediary for Job Satisfaction. 


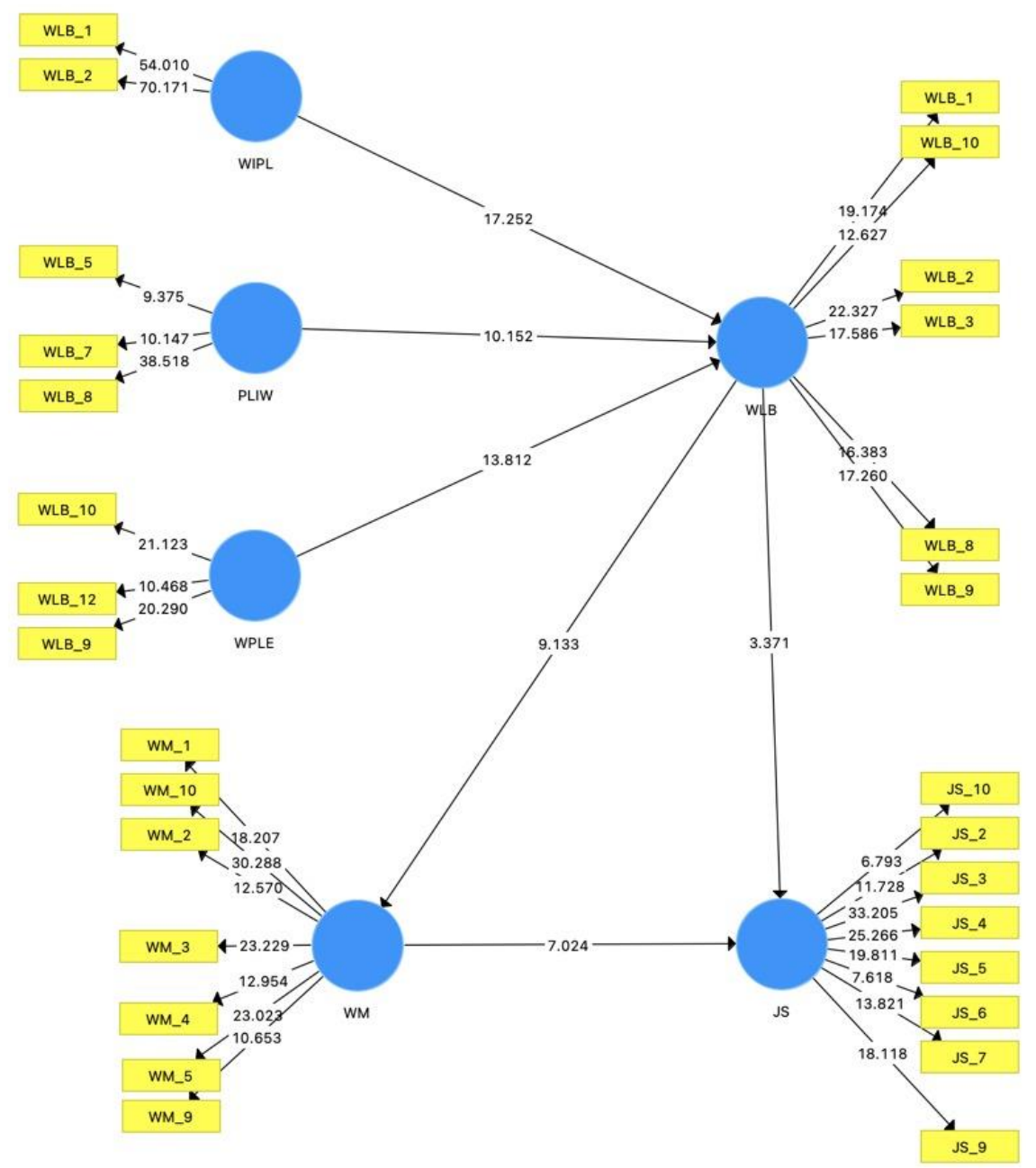

Figure 2. Inner Model

Our hypothesis supports by statistical assessment; therefore, our proposed hypothesis is $\mathrm{H} 1$ : Work-life Balance will positively influence work motivation, H2: Work Motivation will positively influence Job Satisfaction, and H3: work-life balance will positively mediate by work motivation affects job satisfaction, is accepted. We may discuss this according to the items given within the instrument.

The COVID-19 epidemic is now making headlines around the world. With the pandemic spreading, most countries are expanding human proximity limits, sealing boundaries, shifting habits to adapt to healthy living to reduce the effect of coronavirus, and many more. COVID-19 has had a significant economic influence on the world. As the number of coronavirus cases rises and more employers adhere to the social-distancing activities (Zeidner, 2020), health officials hope will help slow the spread of COVID-19, the virus's respiratory illness is a scenario been playing out across the globe. According to research published in a white paper by Skedulo (source: skedulo, 2020), 51 per cent of the data they collected from the workers surveyed indicated that COVID 19 hurt their job satisfaction, this is because perceived work hours have risen significantly, and the company's attempts to help foster a sense of job satisfaction are pretty significant.We

Inayah Alfatihah, Antonius Soelistyo Nugroho, Elmarian Haessel, and Anita Maharani. The Influence of Work-Life Balance with Work Motivation as Mediating Factor on Job Satisfaction A Prediction toward Transition to New Normal Situation 
have proven that work-life balance influence work motivation within people with age between 20-25, graduated as a bachelor and worked in tertiary industry (this, regardless of their gender or marital status). The findings of testing this hypothesis seem to support Mahmoud et al. (2020) and Shafee et al. (2020) within this particular group's belief that work-life balance can make people feel motivated to do important things. However, there is not much detail available to prove who coined the phrase "modern standard." However, according to numerous internet outlets, the new standard happens after a very significant societal transition, and people attempt to adapt to these changes. Zeidner (2020) mention large tech companies, including Apple, Google, Facebook, and Microsoft, which have significant populations in Seattle and other pandemic-affected cities, were among the first to implement remote work plans for several or all of their workers worldwide.

When entering a new normal, these demographic groups will see changing job opportunities and work pressure necessitate understanding how to achieve a work-life balance. (Hite \& McDonald, 2020; Darwish, 2020). Maintaining healthy emotional wellbeing that keeps us motivated comes from striking a balance between life and work. As our items for H1 statement "Work-life Balance", Personal life motivated me to work harder.

Then, we also have proven that work motivation will positively influence job satisfaction within a particular demographic. When entering a new normal, these demographic groups will see motivation as a stage that considers a person's direction and perseverance in achieving goals (Kocman \& Weber, 2016). Within the new normal, motivational issues have become a critical issue in many organizations. Workplace motivation is an attempt to ensure that every employee performs well. Job motivation, it could be said, is concerned with how employees should harness all of their potential and energies to work productively and produce positive work results. When employees are excited about their jobs, they are more likely to be satisfied with their jobs. As our items for the $\mathrm{H} 2$ statement as following "Work Motivation", I chose to attain a particular lifestyle because this is the type of work.

Last, we proved that work-life balance would positively mediate by work motivation affects job satisfaction. When entering a new normal, these demographic groups will see job satisfaction as a positive or negative emotion resulting from an individual's assessment of their level of job satisfaction (Asbari, 2020). Moreover, according to McCutcheon (2014), work-life balance is a severe issue and a critical subject for any working professional. As our items for H3 statement "Job Satisfaction", All my talents and skills are used. Business leaders are busy devising ways for their operations to operate safely in the future as the Covid-19 crisis persists worldwide, especially in an environment where social distancing will need to sustain for the long term. Many more workers will inevitably locate at home, either full-time or part-time, which will be more versatile.

\section{CONCLUSIONS AND RECOMMENDATIONS}

This research aims to see any interesting work-life balance patterns, work motivation, and job satisfaction among employees during the new normal transition phase. Previous research has shown the importance of the relationship between variables, but the current situation is far from natural. The findings of this study are representative of such demographic groups. However, there is still time to test other demographic classes, such as age and sector (in this study, the majority of the participants work in the tertiary industry), and similar studies conduct to assess research models that are commonly use before a pandemic happens, and this has become the new standard. With all change, reverting to old ways of functioning is not a viable option. By embracing new ways of operating, even managing people, businesses have increased their business resilience and speed. Finally, happy workers would help the company's

Inayah Alfatihah, Antonius Soelistyo Nugroho, Elmarian Haessel, and Anita Maharani. The Influence of Work-Life Balance with Work Motivation as Mediating Factor on Job Satisfaction A Prediction toward Transition to New Normal Situation 
The Management Journal of BINANIAGA Vol. 06, No. 01, June 2021

p-ISSN: 2527 - 4317, e-ISSN: $2580-149 x$

$6^{\text {th }}$ Accreditation Rating: April 04, $2019-$ April 03, 2024

growth both internally and externally. The company's commitment and energy in evaluating workers and their work will always represent the company's success.

\section{REFERENCE}

Adnan Bataineh, K. (2019). Impact of work-life balance, happiness at work, on employee performance. International Business Research, 12(2), 99-112.

Asbari,M.,Bernarto, I., Pramono, R., Purwanto,A., Hidayat,D., Sopa,A., Alamsyah, V.U., Senjaya,P., Fayzhall,M. \& Mustofa,M. (2020). The Effect of work-Family conflict on Job Satisfaction and Performance: A Study of Indonesian Female Employees . International Journal of Advanced Science and Technology, 29(3), 6724 - 6748.

Bhalerao, S. K. (2013). Work life balance: The key driver of employee engagement. ASM's International E-Journal of Ongoing Research in Management and IT, 1-9.

Blackburn, J. J., Bunchm, J. C., \& Haynes, J. C. (2017). Assessing the Relationship of Teacher Self-Efficacy, Job Satisfaction, and Perception of Work-Life Balance of Louisiana Agriculture Teachers. Journal of Agricultural Education, 58(1), 14-35.

Chandra, V. (2012). Work-life balance: eastern and western perspectives. The International Journal of Human Resource Management, 23(5), 1040-1056.

Daipuria, P., \& Kakar, D. (2013). Work-life balance for working parents: Perspectives and strategies. Journal of strategic human resource management, 2(1), 45.

Darwish, S. A. A. D., Ahmed, U. M. A. I. R., \& Pahi, M. H. (2020). Innovative work behavior during COVID-19 for medical representative in the pharmaceutical industry: Test of a moderation model in bahrain. International Journal of Pharmaceutical Research, 12(4), 1927-1934.

Davis, K., \& Nestrom, J. W. (1985). Human Behavior at Work: Organizational Behavior,

Gigauri, I. (2020). EFFECTS OF COVID-19 ON HUMAN RESOURCE MANAGEMENT FROM THE PERSPECTIVE OF DIGITALIZATION AND WORK-LIFE-BALANCE. International Journal of Innovative Technologies in Economy, (4 (31)).

Hasan, N. A. B. B., \& Teng, L. S. (2017). Work-life balance and job satisfaction among working adults in Malaysia: The role of gender and race as moderators. Journal of Economics, Business and Management, 5(1), 18-24.

Hayman, J. (2005). Psychometric assessment of an instrument designed to measure work life balance. Research and practice in human resource management, 13(1), 85-91.

Hite, L. M., \& McDonald, K. S. (2020). Careers after COVID-19: Challenges and changes. Human Resource Development International, 23(4), 427-437.

Inayah Alfatihah, Antonius Soelistyo Nugroho, Elmarian Haessel, and Anita Maharani. The Influence of Work-Life Balance with Work Motivation as Mediating Factor on Job Satisfaction A Prediction toward Transition to New Normal Situation 
Kaliannan, M., Perumal, K., \& Dorasamy, M. (2016). Developing a work-life balance model towards improving job satisfaction among medical doctors across different generations. The Journal of Developing Areas, 50(5), 343-351.

Kelliher, C., Richardson, J., \& Boiarintseva, G. (2019). All of work? All of life? Reconceptualising work-life balance for the 21st century. Human Resource Management Journal, 29(2), 97-112.

Kocman, A., \& Weber, G. (2018). Job satisfaction, quality of work life and work motivation in employees with intellectual disability: A systematic review. Journal of Applied Research in Intellectual Disabilities, 31(1), 1-22.

Lavoie, A. (2004). Work-life balance and SMEs: Avoiding the "one-size-fits-all" trap. CFIB Research, 1-13.

Macdonald, S., \& Maclntyre, P. (1997). The generic job satisfaction scale: Scale development and its correlates. Employee Assistance Quarterly, 13(2), 1-16.

Mahmoud, A. B., Fuxman, L., Mohr, I., Reisel, W. D., \& Grigoriou, N. (2020). "We aren't your reincarnation!" workplace motivation across $\mathrm{X}, \mathrm{Y}$ and $\mathrm{Z}$ generations. International Journal of Manpower.

Manivannan, A. S. R. (2019). The Mediating Effect of Work-Life Balance between Motivation and Job Satisfaction and Its Impact on Emotional Intelligence of Mystery Shopping Professionals. SEISENSE Journal of Management, 2(4), 14-34.

Maulana, A. S., Nurdiansyah, R., Permana, A. S., \& Puspa, D. N. (2021). Literature Review of Work Motivation, Job Satisfaction and Job Loyalty. Psychology and Education Journal, 58(3), 469-473.

Maurya, M. K., \& Agarwal, M. (2018). Relationship between motivation to lead, mental health status, and job satisfaction of male and female civil police constables. Journal of police and Criminal Psychology, 33(1), 9-20.

McCutcheon, K. (2014). Work-life balance.

Muliana, Y., \& Makmur, W. A. (2016). Pengaruh Keterlibatan Kerja dan Kepuasan Kerja terhadap Turnover Intention Karyawan pada Pasar Modern Pasir Pengaraian Kabupaten Rokan Hulu. Fakultas Ekonomi, Universitas Pasir Pengaraian, 3(1).

Obeidat, D., Yousef, B., Altheeb, S., \& Masa'deh, R. E. (2018). The impact of internal corporate social responsibility on job satisfaction in Jordanian pharmaceutical companies. Modern Applied Science, 12(11).

Oktosatrio, S. (2018). Investigating the relationship between work-life-balance and motivation of the employees: Evidences From The Local Government of Jakarta.

Inayah Alfatihah, Antonius Soelistyo Nugroho, Elmarian Haessel, and Anita Maharani. The Influence of Work-Life Balance with Work Motivation as Mediating Factor on Job Satisfaction A Prediction toward Transition to New Normal Situation 
The Management Journal of BINANIAGA Vol. 06, No. 01, June 2021

p-ISSN: 2527 - 4317, e-ISSN: $2580-149 x$

$6^{\text {th }}$ Accreditation Rating: April 04, $2019-$ April 03, 2024

Panisoara, I. O., Lazar, I., Panisoara, G., Chirca, R., \& Ursu, A. S. (2020). Motivation and continuance intention towards online instruction among teachers during the COVID-19 pandemic: The mediating effect of burnout and technostress. International Journal of Environmental Research and Public Health, 17(21), 8002.

Parimita, W., Khoiriyah, S., \& Handaru, A. W. (2018). Pengaruh Motivasi Kerja dan Kompensasi terhadap Kepuasan Kerja pada Karyawan PT Tridaya Eramina Bahari. JRMSI-Jurnal Riset Manajemen Sains Indonesia, 9(1), 125-144.

Purwanto, A., Asbari, M., Fahlevi, M., Mufid, A., Agistiawati, E., Cahyono, Y., \& Suryani, P. (2020). Impact of Work From Home (WFH) on Indonesian Teachers Performance During the Covid-19 Pandemic: An Exploratory Study. International Journal of Advanced Science and Technology, 29(5), 6235-6244.

Putra, K. C., Pratama, T. A., Linggautama, R. A., \& Prasetyaningtyas, S. W. (2020). The Impact of Flexible Working Hours, Remote Working, and Work Life Balance to Employee Satisfaction in Banking Industry during Covid-19 Pandemic Period. Journal of Business Management Review, 1(5), 341-353.

Rauan, F. J., \& Tewal, B. (2019). PENGARUH MOTIVASI, LINGKUNGAN KERJA FISIK DAN STRES KERJA TERHADAP KEPUASAN KERJA KARYAWAN PADA PT. TROPICA COCO PRIMA DI LELEMA KABUPATEN MINAHASA SELATAN. Jurnal EMBA: Jurnal Riset Ekonomi, Manajemen, Bisnis dan Akuntansi, 7(4).

Rozzaid, Y., Herlambang, T., \& Devi, A. M. (2015). Pengaruh kompensasi dan motivasi terhadap kepuasan kerja karyawan. Jurnal Manajemen Dan Bisnis Indonesia, 1(2).

SABIR, R. A., \& CURA, D. F. (2021). The Effects of Work-Life Balance on the Academic employees' Performance, Motivation and Job Satisfaction among Private and Public Universities of Kurdistan Region. Journal of Contemporary Issues in Business and Government, 27(2), 674-678.

Said, J., Setyaningrum, R. P., Nugroho, A. T., \& Yulianingsih, S. (2021). The Influence of Organizational Commitment, Job Stress, and Work Motivation on Job Satisfaction (A Study at PT Matsuo Precision Indonesia's Injection Molding Deptin Cikarang).

Salolomo, B., \& Agbaeze, E. (2019). Effect of work-life balance on performance of money deposit banks in south-south Nigeria. Management Science Letters, 9(4), 535-548.

Sánchez-Hernández, M. I., González-López, Ó. R., Buenadicha-Mateos, M., \& TatoJiménez, J. L. (2019). Work-life balance in great companies and pending issues for engaging new generations at work. International journal of environmental research and public health, 16(24), 5122.

Skedulo.(2020).The 2020 State of Work Report: Defining a New Normal Amid COVID-19. Source: info.skedulo.com

Inayah Alfatihah, Antonius Soelistyo Nugroho, Elmarian Haessel, and Anita Maharani. The Influence of Work-Life Balance with Work Motivation as Mediating Factor on Job Satisfaction A Prediction toward Transition to New Normal Situation

Page: 92 
Sekaran, U., \& Bougie, R. (2016). Research methods for business: A skill building approach. John Wiley \& Sons.

Shafee, S., Abdullah, Z., \& Aliasah, M. W. S. (2020). THE IMPACT OF THE WORK-LIFE BALANCE ON WORK MOTIVATION AMONG THE NON-ACADEMIC EMPLOYEES OF PUBLIC HIGHER LEARNING INSTITUTIONS IN MALAYSIA. The Malaysian Journal of Social Administration, 14(2), 1-18.

Shen, J. (2011). Developing the concept of socially responsible international human resource management. The International Journal of human resource management, 22(06), 1351-1363.

Sidabutar, E., Syah, T. Y. R., \& Anindita, R. (2020). The Impact of Compensation, Motivation, and Job Satisfaction on Employee Performance. Journal of Multidisciplinary Academic, 4(1), 1-5.

Smith, K. T. (2010). Work-life balance perspectives of marketing professionals in generation Y. Services Marketing Quarterly, 31(4), 434-447.

Soto-Rubio, Ana., Giménez-Espert, M. D. C., \& Prado-Gascó, V. (2020). Effect of Emotional Intelligence and Psychosocial Risks on Burnout, Job satisfaction, and Nurses' Health during the COVID-19 Pandemic. International Journal of Environmental Research and Public Health, 17(21), 7998.

Tentama, F., \& Pranungsari, D. (2016). The Roles of Teachers' Work Motivation and Teachers' Job Satisfaction in the Organizational Commitment in Extraordinary Schools. International Journal of Evaluation and Research in Education, 5(1), 3945.

Tovmasyan, G., \& Minasyan, D. (2020). The Impact of Motivation on Work Efficiency for Both Employers and Employees also During COVID-19 Pandemic: Case Study from Armenia.

Tremblay, M. A., Blanchard, C. M., Taylor, S., Pelletier, L. G., \& Villeneuve, M. (2009). Work Extrinsic and Intrinsic Motivation Scale: Its value for organizational psychology research. Canadian Journal of Behavioural Science/Revue canadienne des sciences du comportement, 41(4), 213.

William, M. G. (2020). Pengaruh Work Motivation Terhadap Job Satisfaction Melalui Organizational Culture. Jurnal Ekonomi Dan Kewirausahaan Kreatif, 5(2), 52-62.

Wolor, C. W., Solikhah, S., Fidhyallah, N. F., \& Lestari, D. P. (2020). Effectiveness of ETraining, E-Leadership, and Work Life Balance on Employee Performance during COVID-19. The Journal of Asian Finance, Economics and Business (JAFEB), $7(10), 443-450$.

Zeidner, Rita.(2020). Coronavirus Makes Work from Home the New Normal. Source: SHRM.org. Accessed on May 4rd 2021

Inayah Alfatihah, Antonius Soelistyo Nugroho, Elmarian Haessel, and Anita Maharani. The Influence of Work-Life Balance with Work Motivation as Mediating Factor on Job Satisfaction A Prediction toward Transition to New Normal Situation 
The Management Journal of BINANIAGA Vol. 06, No. 01, June 2021

p-ISSN: 2527 - 4317, e-ISSN: $2580-149 x$

$6^{\text {th }}$ Accreditation Rating: April 04, $2019-$ April 03, 2024

Zheng, C., Kashi, K., Fan, D., Molineux, J., \& Ee, M. S. (2016). Impact of individual coping strategies and organisational work-life balance programmes on Australian employee well-being. The International Journal of Human Resource Management, 27(5), 501-526.

Inayah Alfatihah, Antonius Soelistyo Nugroho, Elmarian Haessel, and Anita Maharani. The Influence of Work-Life Balance with Work Motivation as Mediating Factor on Job Satisfaction A Prediction toward Transition to New Normal Situation 